\title{
Interpretation Literary Texts That Breathe on Interdisciplinary in Nature
}

\author{
Otgonsuren Jargal \\ National University of Mongolia, Ulaanbaatar, Mongolia \\ Email: otgonsurenjargal@gmail.com
}

How to cite this paper: Jargal, O. (2019) Interpretation Literary Texts That Breathe on Interdisciplinary in Nature. Open Journal of Social Sciences, 7, 230-237. https://doi.org/10.4236/jss.2019.79017

Received: August 19, 2019

Accepted: September 21, 2019

Published: September 24, 2019

Copyright $\odot 2019$ by author(s) and Scientific Research Publishing Inc. This work is licensed under the Creative Commons Attribution International License (CC BY 4.0).

http://creativecommons.org/licenses/by/4.0/

\section{(c) (i) Open Access}

\begin{abstract}
The analytical point of view of literature is leaning toward the ecological and social change in the world. Based on the concept "words that breathe or texts that breathe" which is initiated idea by doctor Jose Marrero Henriquez for analyzing in eco-criticism, I would like to extend this line of thinking and trying to interpret it. Aforementioned words or literary texts that breathe, appear to be some relationship with meditation, which concentrates on the breath a human being. From this point of view, the eco-analysis of literature is a way of looking at the path between ecocriticism and Buddhism, regardless of tradition. This is an attempt to do interpretation by ecocriticism on novel by Gun Ayurzana, "Shugden" (2012) which talks story of one of separated ethnic groups in Mongolia, interconnected each other to religious and philosophical issues.
\end{abstract}

\section{Keywords}

Eco-Criticism, Ecological Awareness and Literary Landscapes, Interdisciplinary Study, Eastern Philosophy, Buddhism

\section{Introduction}

The art and literature are always led the public thinking and direct it to social and environmental awareness. Ecocriticism in literary study is taking new direction for analyzing and interpreting text within the context of ecological effect of planetary life. Investigating the words that breathe in literature, to seek the subtle connections between human mind and ecology is lead to ecocriticism. In other words, literary criticism not only concentrates on an author's creativity and her writing skills, but also brings to light a series of ecological awareness.

As stated by Dr. Jose Marrero (2015), different aspects of biological and cultural life become interconnected, nature and culture are no longer opposite sites, 
then Ecocriticism and Buddhism may talk about the integrity and significance of human existence.

Literary analysis with an exotic expression "word that breathes" appears to have something similar to diagnosing in pulse in Asian traditional medicine which is also associated with breathing and meditation. By observing the breath, human consciousness awakes, in a similar way, analyzing literary texts that breathing may be able to awaken the eco-consciousness of literature.

Meta narratives and overtones in novel chosen here to explicate from point of view ecocriticism are not easy for the reason that hints for correlations in earthly effects and events in spiritual world.

But if following distinctive utterance of the novel avoiding logical thinking, it may found a possibility to interpret things differently.

In the arts and literature that always go in avant-garde of public thought as an intellectual locomotive of society, a vital issue of ecological awareness and warnings for future trends of nature is concerned.

In the present day, eco-critical researchers are trying to impact on social mentality changes, and acts as conductors, giving ecological alerts which may lead to disasters.

Doctor Jose Marrero who began to introduce himself to ecocriticism at the ends of 1990s in Spain and Latin American literary studies, and had "the audacity to incorporate certain specific themes dedicated to ecocriticism into the area of Comparative Literature and Literary Theory" claims that "But I see on it slightly different way of view and from different edges. The fundamental hypothesis is to consider that written words breathe, and as a consequence, criticism will have to search, analyze, and interpret the procedures through which literary texts breathe, regardless of the tradition to which they belong." [1]

Thus, to feel and diagnose "breath of word" in literature may require no less knowledge than an Asian traditional medicine doctor. This extraordinary idea allowed me to extend the scope of comparisons in Eco-criticism and Buddhist philosophy.

On the other hand, to listen to the "breath of the word", it would appear to be the same as doing meditation. Buddhist major tenets come with meditation and the meditation begins with observing the breath. Therefore, it would the same feelings of word breath in literature.

Eco-philosophy spread in 1960's in Europe. And a man who said loudly about eco-philosophy taking attention of public on it was Norvegian philosopher Arne Naess. He connected eco-philosophy with human being in close proximity to Buddhism. He founded term of Deep Ecology and in his work "The Shallow and the Deep Long-Range Ecology Movement" [2] criticized Europe-North America's man centric civilization, especially its idea that everything in nature is for human needs. His work bore a strong impression to people and significant influence to ecological movements. It describes itself as "deep" because it regards itself as looking more deeply into the actual reality of humanity's relationship 
with the natural world arriving at philosophically more profound conclusions than that of the prevailing view of ecology as a branch of biology. The movement does not subscribe to anthropocentric environmentalism (which is concerned with conservation of the environment only for exploitation by and for human purposes) since deep ecology is grounded in a quite different set of philosophical assumptions.

Arne Naess said "Deep Ecology is not a minor change to be made in a current society, but the whole new reform on civilization's existence basics". On Deep Ecology as he noted critical concept that materialistic interests and greediness of mankind are crumbling the ecology, exactly coincident with Buddhist philosophy.

Academic definition of Deep Ecology based on two following concepts. First of them is "bio-centric egalitarianism" which saying all kinds of life have same rights to co-exist. The other one is metaphysical holism which asserts that the biosphere does not consist of discrete entities but rather internally related individuals that make up an ontologically unbroken whole [3].

Metaphysical holism is pillars on Buddhist worship. Buddhism believes wholes of existence. Yet internal linkage and dependence, phenomena of nature all have spiritual quality and as one whole system interpreted as Deep Ecology. As you can see, meta descriptions in literature and phenomena's in nature, society and human mind would be closely linked to ecocriticism.

Eco-analysis in literature studies must be taken on intersection point of Nature-Man. The original intersection point starts when a child born from mother's womb begins to breathe the air.

The breath is only connection between us to the nature. The breath is probe that man is alive. All living creatures connect with nature through its breathe.

The entire novel Shugden by G. Ayurzana, tells the story about one Buddhist mysterious relic and how that relic influencing to human mind and real life. And there are lots of metanarratives expressing relic's influence to open and hidden world's nexus, connected with nature phenomena and impossible to explain logically. Main character utterance and sense described in very oriental way. Especially its interesting how Buddhist philosophical notions presented in cognitive way through Samand lama's talks.

Buddha's major teaching is lead people to great changes by doing meditation which starts from observing breath. To plunge deeply into internal world a man has to peer into internal dark corners of his own mind.

"The key to unlock the secret of internal world lies inside of you, so just look for it and calmly observe your breath. Meditation must be simple and continuous process as breath. I'll point the way and if you want to follow it. But don't follow it just because I said it. You have to experience that way by yourself" [4].

A. Govinda, who was the first Western lama, well known and respected by Tibetans during his lifetime, notes that consciously observing respiration forms four basics of focusing attention and seven factors of enlightenment and there- 
fore leads to perfect enlightenment and pure freedom. Meditation is not only an excursion to own inner world, but also first step in campaign to understand and identify the universe [5].

In the same way, observing "word of breath" in literature we may understand author's ideas and hidden meanings.

"... They sat in silence for a long time. For Samand to sit in silence and listen to lady's breath was real happiness. But for Dulmaa it was uncomfortable to sit without talking long while, so she stood up not knowing what to say." [6]

Feeling the vibration of joy, light and heat from all around while just sitting in silent, is the way to get into own inner depth. And it is one kind of Zen meditation. And Dr. D. T Suzuki notes; "Meditational practices have, therefore, no other purpose than to awaken, to develop, and to strengthen the awareness of the individual, to remove the hindrances that stand in the way of the free flow of creative and life-giving energies, to open the mind to the infinite possibilities of experience." [7]

As explained Anagarika Govinda, “... As soon as we succeed in silencing the restless activity of our intellect and give our intuition a chance, the pure all-embracing spirit in us will manifest itself. ... The moment we open our inner eye instead of looking outward into world of apparent material reality, illusion disappears, and we suddenly become aware of true reality. This is why the Dhyana school speaks of 'sudden enlightenment"' [8]

In "Shugden" novel: "Body is just a whole piece of meat which takes moving power from fire of breath. So that do not think much about body, said Saint Ajaa." [9]

In Eastern countries, especially followers of Buddhism, "Saint" is highly respected lama (monk) with deep knowledge of Buddhism and mysticism which is related directly to spiritual knowledge.

In order to hint aforementioned quotation, we need to apprehend the core perception of meditation and breath that is connected by roots to eco-criticism.

The purpose of doing meditation is to make quiet your thoughts and temporarily empty your always active mind then the sixth sense becomes sharp and clear.

Samand lama's/monk/intelligent talks, simple but leading to deep thoughts ideas inevitably attract serious readers. In the novels it is common when unexpected events turning story course the way you'll never imagine, yet the basic tone always kept its bright and transparent forms.

"Very strange things were happened. I grew fainted. And there was an earthquake. And when I seize the life days of passed away I lied unconscious ..." "From dead friend's home I found a scripture. And I read the whole scripture aloud. Then dead friend's younger sister came to take the remains. She was waiting for it in my home drinking a tea. When I heard dog's howl, I was black out. But ... Was that limited domestic earthquake? It is very strange ... Is there some magic secret reason for all of it? Is it possible?" 
“... Right after returning of teacher Badamjunai from India, rocks and mountains began to be destroyed. But lovon teacher stopped the earthquake by power of his preach. Legend says that he built the monastery there and spread the religion" ... [10]

There is a mysterious correlation between the human and non-human worlds which is impossible to explain that things we feel which exists far beyond the level of ordinary people's sensibility. It's unacceptable and naïve conclusion for religion, culture and arts scholars and researchers.

As claimed Dr. Jose Marerro that "Neither religion tradition nor technological progress has a reason to be necessary against the ecological awareness nor its literary and critical manifestations".

Everything exists with their own natural order, then ecocriticism discusses how that natural signals and alerts sensitively and believably reflected in literature.

This novel is not just a story about dead lama in Tibetan monastery and earthquake happening, but there is something more deeply rooted mysterious connection of karma between Samand lama and his childhood friend's Darambal lama, was killed in the yard of monastery.

From the point of view eco-criticism, it relates to metaphysical holism that cannot be understood without interconnection to whole existence (or spirit and ecology are interdependent). In previous quote is an alerting signal for awakening consciousness to present generation learning lessons this story and reconsider faith and conceptual errors.

Doctor Jose Marrero suggests that, “... If culture forms part of nature, complex forms of literary writing seek to capture the immediate knowledge of nature ... ecocriticism should explore the trans bordering possibility of revealing the processes by which words breathe or, in other words, the processes by which literature proves to be the ultimate result of the natural evolution that rewards those who are able to grasp its beauty, that is, its regularities in time as well as its regularities in space." JMMH [11]

Shugden's story of mysterious relic tells us that if religion teachers and distributors didn't follow saint rules and use preachment for enlightenment in wrong purpose, in hands of hostile groups it becomes a weapon to destruct each other. That explains existence of so called "secret tantric rules" in Buddhism. Texts of "Secret tantric rules" filled with numbers of phrases with symbolic, double and hidden meanings. As Lama Govinda said, "it was adopted not in purpose to hide Buddhist secrets from intellectual people, but to avoid using them by stupid men as a self-destructing weapon". [12]

Possibly when human greediness and ignorant actions distort true meaning of creed of enlightenment and magic relics containing power of secret tantric used for frameless material needs, then harmonious pulse of Man-Nature-Supreme spirit internal communication and nexus become unstable. And may be nature hints and reminds us about it by own language. 
Beyond the novel's narrative there is an idea that nature exists not just to meet human greedy needs and fight for wealth and power is pipsqueak/nobody/ comparing with expansion of the mind longing to reach supreme spirit and enlightenment.

According to ecocriticism, even by deep ecology inner communications and correlations of nature should be always considered. Nature as a whole, permit existence of human and all other life forms inside of itself [13].

In the novel talks some mysterious correlation between the death lama Darambal and the police dog's death and also weird coincidence that happened earthquake in the place, from where he (Darambal) took the puppy.

Opened golden box showed that he called for a dog. So this dog ... Saint teacher of my passed away brother clearly told what was written in his golden box. There was written that he wanted to go to his last trip not alone, but with a dog. We never heard that brother had a dog. So he'll call this dog... He sat down on the road and murmured, "This dog will go after him"...

But Samand after hearing that in the golden box was written about a dog not surprised. Maybe he had a certain plan when brought a puppy. His death, "Sonsgood" book in his home, his golden book's letter of dispensation and hound dog who suddenly dead. ... All interconnected? It seems to be so ...

Why he was saying that he is an incarnation khuvilgaan? Had he a reason to?'

After woman's talk the cause of mysterious death of his friend approached one step closer to detection. Shocked but happy with findings he mouthed off, "Darmaa already took the dog described in his golden box" [14].

In Asian some countries have a special (religious) ritual named "to open golden box" once after death. The monk who specialized open this box, read the written in it, usually there talks the reason of death of the person and also predict her/his reincarnation in next life.

To explain universe-nature-man correlation and interdependence must be viewed from different angles such as astronomy and Eastern astrology etc. It's not easy to hunt for correlations of materialistic world from events going on in spiritual world. But if to plunge depth ward to eco concept it's possible to interpret things differently.

... "For the first time $1 \mathrm{~m}$ going to look at a track of animal went to the lord of death. So for faith Pll imagine he was a man", said astrologer. "Some words gained Serjamt's ear."

"Extraordinary strong guardian spirit will seize twist of fate of someone born in tiger year ... A man suffered from a thousand-year long journey left this world for beggarly asking a transportation".

"In the end, he thought that a man had a horse year... His life days ended and spirit wandered in the evening twilight four months before greeting lord of death ..." [15]

Meta-narration of this novel is human life and nature are deeply rooted connection that could be explained as spiritual consistent, but not relationship to 
the Earthly meaning.

Moreover, there is hidden (subtle) idea that our ancestor's intellectual data still have kept in their native land (nature), waiting the time comes to restore interrupted historical circuit and signalizing to make updates in their memory. This is the theme that may be explained by Jungian archetype. But here more focused and trying to interpret by refusing of logical thinking that is linked to line between spiritual and phenomenal thing in relationship with human life and nature.

\section{Conclusions}

All this mysterious content of the novel is an exploration of a logical paradox and phenomena of the religious belief. The paradox that is to be found throughout Ayurzana's work may be related to ecocriticism which is rooted in the whole existence of the Universe.

The ecocriticism that characterizes an era, undertaken in America, gradually spread now in Asian Universities, and would have a potential to change human mindset.

Thus analyzing in ecocriticism of literature is not the matter beyond human life that does not concern the scope of ecological issues.

The phenomena of nature and mind in literature can be explained by the existence of hidden world, spirit or by metaphysical holism theory, but there is no sole suitable explanation for it.

Supporting Professor Ch. Biligsaikhan's idea that takes the view that (2000) "literature became more linked to the philosophy, deep thought and meditation", I tried to do explanation that eco-criticism could have to search, analyze, and interpret literary texts on interdisciplinary (trans bordering) study including Buddhism philosophy, Eastern and Western psychology.

Just as meditation observing breathing will awaken consciousness, the analysis explores the words that breathe in literary texts that connecting with eco concept probably reveal knowledge of relationships binding the universe and in promoting the cultural interaction.

\section{Conflicts of Interest}

The author declares no conflicts of interest regarding the publication of this paper.

\section{References}

[1] Henriquez, J.M.M. (2015) Word That Breath. 116.

[2] Naess, A. (1989) Deep Ecology. Encyclopedia of Environmental Ethics and Philosophy, 2nd Edition, 45.

[3] http://www.uky.edu/OtherOrgs/AppalFor/Readings/240\%20-\%20Reading\%20-\%20 Deep\%20Ecology.pdf

[4] Лувсанцэрэн, Г. (1987) Буддын философийн түүхээс. 37. 
[5] Govinda, A. (1969) Foundation of Tibetan Mysticism. 150.

[6] Аюурзана, Г. (2012) Шүгдэн. 214.

[7] Power, R. (2013) The Lost Teachings of Lama Govinda. 27.

[8] Power, R. (2013) The Lost Teachings of Lama Govinda. 12.

[9] Аюурзана, Г. (2012) Шүгдэн. 132.

[10] Аюурзана, Г. (2012) Шүгдэн. 119-120.

[11] Henriquez, J.M.M. (2015) @Ecozon@. Vol. 6, 116.

[12] Говинда (2013) Буддын тантрын үндэс. 212.

[13] Аюурзана, Г. (2012) Шүгдэн. 127.

[14] Аюурзана, Г. (2012) Шүгдэн. 195.

[15] Билигсайхан, Ч. (2000) Бичгийн мэргэдийн билгүүн товчоон. 311. 